\title{
COMPARISON OF THREE METHODS FOR ADJUSTING SCROTAL CIRCUMFERENCE IN CHAROLAIS, LIMOUSIN AND HUNGARIAN FLECKVIEH YOUNG BULLS UNDER FARM CONDITIONS
}

\author{
J. TÖZSÉR ${ }^{1}$ and M. MÉZES ${ }^{2}$ \\ ${ }^{1}$ Institute of Animal Husbandry and ${ }^{2}$ Department of Nutrition, Gödöllő University \\ of Agricultural Sciences, H-2103 Gödöllö, Páter K. u. 1, Hungary
}

(Received January 30, 1998; accepted April 3, 1998)

\begin{abstract}
This study was conducted to compare three different methods for calculating scrotal circumference $\left(\mathrm{ASC}_{1}, \mathrm{ASC}_{2}, \mathrm{ASC}_{3}\right.$ ) adjusted to 365 days of age in Charolais, Limousin and Hungarian Fleckvieh young bulls at the end of the selfperformance test. Young breeding bulls from three Charolais, Limousin and Hungarian Fleckvieh breeding farms (farm A: $n=40$; farm B: $n=9$; farm C: $n=11$ ) were used. The young bulls were kept in loose housing system, in small groups, and fed a diet based on maize silage and concentrate. The scrotal circumference of young bulls was measured at the widest part of the scrotum at the beginning and at the end of the test. Significant growth was observed $(+13.6 \mathrm{~cm} ;+8.9 \mathrm{~cm} ;+10.5 \mathrm{~cm}$, $\mathrm{P}<0.001)$ in scrotal circumference (SC) for all breeds except the Hungarian Fleckvieh $\left(\mathrm{ASC}_{2}-\mathrm{ASC}_{3}: 37.5\right.$ vs. $\left.37.6 \mathrm{~cm}\right)$. All differences among the means of the measured and adjusted SCs were statistically confirmed at the $\mathrm{P}<0.05$ level of significance. A moderate to close positive correlation $(\mathrm{r}=0.49-0.99)$ was calculated among the measured SC and the three types of ASC. The results suggest that method I $\left(\mathrm{ASC}_{1}\right)$ and method II $\left(\mathrm{ASC}_{2}\right)$ should be used by the breeders for adjusting scrotal circumferences in the practice.
\end{abstract}

Key words: Bull, scrotal circumference, selection

Scrotal circumference (SC) of young bulls is a potentially useful indicator of reproductive potential in beef cattle. SC is positively correlated with total sperm production (Hahn et al., 1969; Coulter and Foote, 1979; Laszczka and Wierzbowski, 1984; Belloir et al., 1984; Zhang et al., 1993; Gábor et al., 1997) and with the quality of sperm (Brinks et al., 1978; Knights et al., 1984; Gipson et al., 1987; Temblador and Gonzalez, 1988; Polupan, 1994) but negatively with age at puberty (Brinks et al., 1978; King et al., 1983; Vargas et al., 1997). SC has been found to be correlated positively with the age at puberty in daughters (Moser et al., 1996), pregnancy rates, age at first breeding and age at first calving in females (Lunstra, 1985; Toelle and Robinson, 1985; Smith et al., 1987). 
In most of the previous reports the heritability estimated for SC ranged between 0.4 and 0.7 (Coulter and Keller, 1979; Latimer et al., 1982; Neely et al., 1982; Lunstra et al., 1985; Lunstra et al., 1988; Kriese et al., 1991; Gregory et al., 1995; Keeton et al., 1996; Shepard et al., 1996).

If $\mathrm{SC}$ is used as a selection criterion in yearling bulls, some attention should be given to adjustments to account for differences in age (Bell et al., 1996) and age of dam (Kress et al., 1996) among bulls.

The following adjustment formula is used generally in the USA (Lunstra et al., 1985):

Adjusted SC $=[($ linear regression coefficient $) \times(365-$ actual age of bull in days) + (actual SC)] + age of dam adjustment

Some linear regression coefficients (b) for SC (Hereford, $n=4233, b=$ $0.026 \mathrm{~cm} /$ day; Hereford and Angus, $\mathrm{n}=779, \mathrm{~b}=0.024 \mathrm{~cm} /$ day; Limousin, $\mathrm{n}=222$, $\mathrm{b}=0.026 \mathrm{~cm} /$ day; Charolais, $\mathrm{n}=197, \mathrm{~b}=0.013 \mathrm{~cm} /$ day; Simmental, $\mathrm{n}=238, \mathrm{~b}=$ $0.034 \mathrm{~cm} /$ day; 12 breed, $\mathrm{n}=3094, \mathrm{~b}=0.032 \mathrm{~cm} /$ day) were demonstrated by Lunstra et al. (1985), Bourdon and Brinks (1986) and Smith et al. (1987). Wilson $(1996)$ published a linear regression coefficient $(b=0.0312 \mathrm{~cm} /$ day $)$ for $\mathrm{SC}$ from 50,672 Angus yearling bulls. In this case the average SC was just over $36 \mathrm{~cm}$ and extreme values ranged from a low of $21 \mathrm{~cm}$ to a high of $50 \mathrm{~cm}$. It is very interesting that the standard deviation (SD) for that Angus population was just over $3 \mathrm{~cm}$.

In Hungary, Tőzsér et al. (1993) reported some linear regression coefficients for age $(\mathrm{n}=51, \mathrm{~b}=0.028 \mathrm{~cm} /$ day; $\mathrm{n}=50, \mathrm{~b}=0.050 \mathrm{~cm} /$ day $)$ and liveweight $(\mathrm{n}=51$, $\mathrm{b}=0.039 \mathrm{~cm} / \mathrm{kg} ; \mathrm{n}=52, \mathrm{~b}=0.032 \mathrm{~cm} / \mathrm{kg}$ ) in Charolais bull-calves of 6-7 months of age. The adjustment of SCs for age and liveweight in Charolais bulls of 12-14 months of age has already been calculated by Tözsér et al. (1995).

Pratt et al. (1991) compared two methods (simple method, method of regression analysis) of adjusting SC to 365 days of age and found that overall means calculated for each method were not different in either data set.

The present study was conducted to compare the results of three different methods for calculating an adjusted scrotal circumference (ASC) to 365 days of age in Charolais, Limousin and Hungarian Fleckvieh young bulls at the end of performance test under farm conditions.

\section{Materials and methods}

Young breeding bulls from three Charolais, Limousin and Hungarian Fleckvieh breeding farms (farm A: $n=40$; farm B: $n=9$; farm C: $n=11$ ) were used in the study. At each farm, the young bulls were kept in loose housing system, in small groups, and fed a diet based on maize silage and concentrate. 
The SC of young bulls was measured using a measuring band $(\mathrm{cm})$ at the beginning and at the end of the test, at the widest part of the scrotum (Taylor, 1984). The adjusted SCs was calculated by the following three different methods:

Method I (ASC $\left.{ }_{1}\right)$ according to Tözsér et al. (1995):

$\mathrm{ASC}_{1}=\mathrm{SC}_{2}+\left[\mathrm{b}_{1} \times\left(\mathrm{AAGE}-\mathrm{AGE}_{2}\right)\right]+\left[\mathrm{b}_{2} \times\left(\mathrm{W}_{2}-\mathrm{AW}\right)\right]$,

where: $\quad \mathrm{ASC}_{1}=$ adjusted scrotal circumference, $\mathrm{cm}$

$\mathrm{SC}_{2}=$ measured scrotal circumference at the end of test, $\mathrm{cm}$

AAGE $=$ average age of bulls at the end of test, days

$\mathrm{AGE}_{2}=$ actual age of bull at the end of test, days

$\mathrm{b}_{1}=$ adjustment factor for age, $\mathrm{cm} /$ day of age (Charolais: $-0.014 \mathrm{~cm} /$ day; Limousin: $-0.021 \mathrm{~cm} /$ day; Hungarian Fleckvieh: $0.064 \mathrm{~cm} /$ day)

$\mathrm{W}_{2}=$ actual liveweight of bulls, $\mathrm{kg}$

$\mathrm{AW}=$ average liveweight of bulls at the end of test, $\mathrm{kg}$

$\mathrm{b}_{2}=$ adjustment factor for liveweight, $\mathrm{cm} / \mathrm{kg}$ (Charolais: $-0.003 \mathrm{~cm} /$ $\mathrm{kg}$; Limousine: $0.024 \mathrm{~cm} / \mathrm{kg}$; Hungarian Fleckvieh: $0.038 \mathrm{~cm} / \mathrm{kg}$ )

Method II (ASC 2$)$ according to Lunstra et al. (1985):

$\mathrm{ASC}_{2}=\mathrm{SC}_{2}+\mathrm{b}_{1} \times\left(365-\mathrm{AGE}_{2}\right)$,

where: $\quad \mathrm{ASC}_{2}=$ adjusted scrotal circumference, $\mathrm{cm}$

$\mathrm{SC}_{2}=$ measured scrotal circumference at the end of test, $\mathrm{cm}$

$365=$ constant for age of bull, days

$\mathrm{AGE}_{2}=$ actual age of bull at the end of test, days

$\mathrm{b}_{1}=$ adjustment factor for age, $\mathrm{cm} /$ day of age (Charolais: $-0.014 \mathrm{~cm} /$ day; Limousin: $-0.021 \mathrm{~cm} /$ day; Hungarian Fleckvieh: $0.064 \mathrm{~cm} /$ day)

Method III ( $\left.\mathrm{ASC}_{3}\right)$ according to Pratt et al. (1991):

$\mathrm{ASC}_{3}=\left\{\left[\left(\mathrm{SC}_{2}-\mathrm{SC}_{1}\right): \mathrm{DTEST}\right] \times\left(365-\mathrm{AGE}_{1}\right)\right\}+\mathrm{SC}_{1}$

where: $\quad \mathrm{ASC}_{3}=$ adjusted scrotal circumference, $\mathrm{cm}$

$\mathrm{SC}_{2}=$ measured scrotal circumference at the end of test, $\mathrm{cm}$

$\mathrm{SC}_{1}=$ measured scrotal circumference at beginning of test, $\mathrm{cm}$

DTEST $=$ duration of the test, days

$365=$ constant for age of bull, days

$\mathrm{AGE}_{1}=$ actual age of bull at the beginning of test, days

To describe the relationships among measured (SC) and adjusted $\left(\mathrm{SC}_{1-3}\right)$ scrotal circumferences, the method of linear analysis of regression (one-variable) and correlation was used (Snedecor and Cochran, 1976). The differences between the compared means were determined by the paired Student's $t$-test. 


\section{Results and discussion}

The average values of age, liveweight and SC of Charolais, Limousin and Hungarian Fleckvieh young bulls are summarised in Table 1. Significant growth was observed $(+13.6 \mathrm{~cm} ;+8.9 \mathrm{~cm} ;+10.5 \mathrm{~cm}, \mathrm{P}<0.001)$ in SC for all the three breeds. In a previous study conducted by Schramm et al. (1989), the change in SC during the test was $+8 \mathrm{~cm}$ and $+9 \mathrm{~cm}$ in Charolais and Simmental bulls, respectively.

Coulter (1982) proposed to give priority to young bulls with an SC exceeding $20.0 \mathrm{~cm}$. In this study, the proportion of bulls with an SC greater than $20.0 \mathrm{~cm}$ was $95 \%, 55.5 \%$ and $100 \%$ at farm A, farm B and farm C, respectively.

The SC measured for Charolais and Hungarian Fleckvieh bulls at the end of test was similar to values published by de Rose et al. (1988), Schramm et al. (1989) and Tózsér et al. (1996). The minimum SCs for Charolais, Limousin and Simmental bulls of 12-14 months of age $(32 \mathrm{~cm}, 30 \mathrm{~cm}, 32 \mathrm{~cm})$ were reported by Coulter (1986). Hence, the objective of the breeders should be to select superior bulls, not just those which are barely adequate.

The results of three different methods for calculating an $\mathrm{SC}$ adjusted to 365 days of age are shown in Table 2. Using method I (ASC $)_{1}$ ) for adjusted SC, identical means were obtained as without adjustment, but the values of standard deviation were different in the Limousin (1.76 vs. 2.30) and Hungarian Fleckvieh (2.31 vs. 3.47) breeds. The two values of standard deviation (2.66 vs. 2.61) were almost the same in Charolais bulls.

According to the $t$-test, with the exception of one relationship (Hungarian Fleckvieh, $\mathrm{ASC}_{2}-\mathrm{ASC}_{3}: 37.5$ vs. $37.6 \mathrm{~cm}$ ) all differences among the means of the measured and adjusted SCs were statistically different at the $\mathrm{P}<0.05$ level of significance. For all three breeds, the means of measured SC were higher $(+6.5 ;+1.6 ;+1.2 \mathrm{~cm}, \mathrm{P}<0.01 ; \mathrm{P}<0.001)$ than the results obtained by method III $\left(\mathrm{ASC}_{3}\right)$. The differences between results calculated by method II $\left(\mathrm{ASC}_{2}\right)$ and method III $\left(\mathrm{ASC}_{3}\right)$ were as follows: $\left.+7.8 ;+2.2 ;-0.1 \mathrm{~cm}, \mathrm{P}<0.001, \mathrm{P}>0.05\right)$. It would seem that the three methods used for calculating ASC can produce very different results. These results were at variance with those observed by Pratt et al. (1989).

However, in the present study moderate to high positive correlations $(\mathrm{r}=$ 0.49-0.99) were calculated among the measured SC and the three adjusted SCs $\left(\mathrm{ASC}_{1-3}\right)$. These correlation coefficients can be taken into consideration in the procedures of adjustment (Table 3 ).

The coefficients of correlation (r) between $\mathrm{ASC}_{1}$ and $\mathrm{ASC}_{2}$ varied from 0.88 to $0.99(\mathrm{P}<0.001)$. At the same time, moderate correlation coefficients $(\mathrm{r}=$ $0.51-0.87, \mathrm{P}<0.001)$ were obtained between $\mathrm{ASC}_{1}$ and $\mathrm{ASC}_{3}$. 
Table 1

Age, liveweight and scrotal circumference of Charolais, Limousin and Hungarian Fleckvieh young bulls at the start and at the end of test (mean \pm SD)

\begin{tabular}{|c|c|c|c|c|c|c|}
\hline \multirow{2}{*}{ Parameters } & \multicolumn{2}{|c|}{$\begin{array}{c}\text { Farm A } \\
\text { (Charolais) }\end{array}$} & \multicolumn{2}{|c|}{$\begin{array}{l}\text { Farm B } \\
\text { (Limousin) }\end{array}$} & \multicolumn{2}{|c|}{$\begin{array}{c}\text { Farm C } \\
\text { (Hungarian Fleckvieh) }\end{array}$} \\
\hline & $\mathrm{SC}_{1}$ & $\mathrm{SC}_{2}$ & $\mathrm{SC}_{1}$ & $\mathrm{SC}_{2}$ & $\mathrm{SC}_{1}$ & $\mathrm{SC}_{2}$ \\
\hline Number of bulls & \multicolumn{2}{|c|}{40} & \multicolumn{2}{|c|}{9} & \multicolumn{2}{|c|}{11} \\
\hline Age (day) & $274 \pm 37.80$ & $463 \pm 37.80$ & $241 \pm 18.43$ & $394 \pm 18.43$ & $232 \pm 16.96$ & $385 \pm 16.96$ \\
\hline Liveweight (kg) & $337 \pm 54.42$ & $602 \pm 54.23$ & $283 \pm 21.44$ & $492 \pm 35.53$ & $340 \pm 35.02$ & $593 \pm 51.26$ \\
\hline Scrotal circumference $(\mathrm{cm})$ & $24.2 \pm 2.57$ & $37.8 \pm 2.66$ & $21.2 \pm 2.25$ & $30.1 \pm 1.76$ & $28.3 \pm 3.86$ & $38.8 \pm 2.31$ \\
\hline
\end{tabular}

Abbreviations: $\mathrm{SC}_{1}=$ scrotal circumference at the start of the test; $\mathrm{SC}_{2}=$ scrotal circumference at the end of the test

\section{Table 2}

Mean and standard deviation for adjusted scrotal circumferences of Charolais, Limousin and Hungarian Fleckvieh young bulls by three different methods

\begin{tabular}{|c|c|c|c|}
\hline Parameters & $\begin{array}{c}\text { Farm A } \\
\text { (Charolais) }\end{array}$ & $\begin{array}{c}\text { Farm B } \\
\text { (Limousine) }\end{array}$ & $\begin{array}{c}\text { Farm C } \\
\text { (Hungarian Fleckvieh) }\end{array}$ \\
\hline Number of bulls & 40 & 9 & 11 \\
\hline Adjusted scrotal circumference $1(\mathrm{~cm}), \mathrm{ASC}_{1}$ & $37.8 \pm 2.61$ & $30.1 \pm 2.30$ & $38.8 \pm 3.47$ \\
\hline Adjusted scrotal circumference $2(\mathrm{~cm}), \mathrm{ASC}_{2}$ & $39.1 \pm 2.61$ & $30.7 \pm 1.71$ & $37.5 \pm 2.05$ \\
\hline Adjusted scrotal circumference $3(\mathrm{~cm}), \mathrm{ASC}_{3}$ & $31.3 \pm 2.29$ & $28.5 \pm 2.16$ & $37.6 \pm 1.96$ \\
\hline
\end{tabular}


Table 3

Correlation coefficients (r) between measured scrotal circumference and three adjusted scrotal circumferences $\left(\mathrm{ASC}_{1-3}\right)$

\begin{tabular}{ccccc}
\hline $\begin{array}{c}\text { Herds and number } \\
\text { of bulls }\end{array}$ & Traits & $\begin{array}{c}\mathrm{SC} \\
(\mathrm{cm})\end{array}$ & $\begin{array}{c}\mathrm{ASC}_{1} \\
(\mathrm{~cm})\end{array}$ & $\begin{array}{c}\mathrm{ASC}_{2} \\
(\mathrm{~cm})\end{array}$ \\
\hline Farm A & $\mathrm{ASC}_{1}(\mathrm{~cm})$ & $0.99^{* *}$ & - & - \\
$($ Charolais $)$ & $\mathrm{ASC}_{2}(\mathrm{~cm})$ & $0.98^{* *}$ & $0.99^{* *}$ & - \\
$\mathrm{n}=40$ & $\mathrm{ASC}_{3}(\mathrm{~cm})$ & $0.62^{* *}$ & $0.51^{* *}$ & $0.49^{* *}$ \\
\hline Farm B & $\mathrm{ASC}_{1}(\mathrm{~cm})$ & $0.91^{* *}$ & - & - \\
$($ Limousin $)$ & $\mathrm{ASC}_{2}(\mathrm{~cm})$ & $0.98^{* *}$ & $0.95^{* *}$ & - \\
$\mathrm{n}=9$ & $\mathrm{ASC}_{3}(\mathrm{~cm})$ & $0.93^{* *}$ & $0.77^{*}$ & $0.84^{*}$ \\
\hline Farm C & $\mathrm{ASC}_{1}(\mathrm{~cm})$ & $0.99^{* *}$ & - & - \\
$($ Hungarian Fleckvieh) & $\mathrm{ASC}_{2}(\mathrm{~cm})$ & $0.88^{* *}$ & $0.88^{* *}$ & - \\
$\mathrm{n}=11$ & $\mathrm{ASC}_{3}(\mathrm{~cm})$ & $0.88^{* *}$ & $0.87^{* *}$ & $0.88^{* *}$ \\
\hline
\end{tabular}

Abbreviations: $\mathrm{SC}=$ actual scrotal circumference; $\mathrm{ASC}_{1-3}=$ adjusted scrotal circumferences $1-3$; Levels of significance: ${ }^{*} \mathrm{P}<0.01,{ }^{* * *} \mathrm{P}<0.001$

The results of this study suggest that both method I $\left(\mathrm{ASC}_{1}\right)$ and method II $\left(\mathrm{ASC}_{2}\right)$ can be used for the calculation of adjusted scrotal circumference. As SC seems to be generally related to the bulls' liveweight and age, we recommend that breeders should use method I $\left(\mathrm{ASC}_{1}\right)$ for that purpose.

The following conclusions can be drawn from this study. (i) To judge the reproductive status, the SC of young beef bulls can be measured and adjusted to 365 days of age or to age and liveweight using an adjustment formula. (ii) Different methods of calculating adjusted scrotal circumference can give very dissimilar results. (iii) This study should be repeated and confirmed using new samples of beef bulls.

\section{Acknowledgement}

This work was supported by a grant from the Hungarian Scientific Research Fund (OTKA F-5446) to J. T.

\section{References}

Bell, D. J., Spitzer, J. C., Bridges, W. C. and Olson, L. W. (1996): Methodology for adjusting scrotal circumference to 365 or 452 days of age and correlation of scrotal circumference with growth traits of beef bulls. Theriogenology 46, 659-669.

Belloir, P., Lafortune, E. and Gauthier, D. (1984): Sperm production of Criollo bulls. Ann. Zootech. 33, 551-561. 
Bourdon, J. K. and Brinks, J. S. (1986): Scrotal circumference in yearling Hereford bulls: adjustment factors, heritabilities and genetic, environmental and phenotypic relationships with growth traits. J. Anim. Sci. 62, 985-967.

Brinks, J. S., McInerney, M. J. and Chenoweth, P. J. (1978): Relationship at age of puberty in heifers to reproductive traits in young bulls. Proc. West. Sect. Am. Soc. Anim. Sci. 28, 29 (abstract).

Coulter, G. H. (1982): Business for testicle sire. Proc. Ann. Conf. Agric. Inst. and E. T. in Beef Cattle. Denver, USA, pp. 28-32.

Coulter, G. H. (1986): Aspects of selection and management of the beef bull for reproductive performance. XXIst World Charolais Federation, Calgary, Alberta, Canada, pp. 1-15.

Coulter, G. H. and Foote, R. H. (1979): Bovine testicular measurements as indicators of reproductive performance and their relationship to productive traits in cattle: a review. Theriogenology 11, 297-303.

Coulter, G. H. and Keller, D. G. (1979): Scrotal circumference and its heritability in yearling beef bulls. J. Anim. Sci. 48 (Suppl. 1), 145 (abstract).

de Rose, E. P., Wilton, J. W. and Schaeffer, L. R. (1988): Estimation of variance components for traits measured on station-tested beef bulls. J. Anim. Sci. 66, 62-634.

Gábor, Gy., Sasser, R. G., Falkay, G., Bozó, S., Völgyi-Csik, J., Bárány, I. and Boros, G. (1997): Comparative testicular echo texture and sperm production of young and older HolsteinFriesian bulls. J. Anim. Sci. 75 (Suppl. 1), 118 (abstract).

Gipson, T. A., Vogt, O. W., Ellersieck, M. R. and Massey, J. W. (1987): Genetic and phenotypic parameter estimates for scrotal circumference and semen traits in young beef bulls. Theriogenology 28, 547-555.

Gregory, K. E., Cundiff, L. V. and Koch, R. M. (1995): Genetic and phenotypic variances for production traits of intact male populations of pure bred and composite beef cattle. J. Anim. Sci. 73, 2227-2234.

Hahn, J., Foot, H. and Seidel, G. E. (1969): Testicular growth and related sperm output in dairy bulls. J. Anim. Sci. 29, 41-47.

Keeton, L. L., Green, R. D., Golden, B. L. and Anderson, K. J. (1996): Estimation of variance components and prediction of breeding values for scrotal circumference and weaning weight in Limousin cattle. J. Anim. Sci. 74, 31-36.

King, R. G., Kress, D. D., Anderson, D. C., Doornbos, D. E. and Burfening, P. J. (1983): Genetic parameters in Hereford for puberty in heifers and scrotal circumference in bulls. Proc. West. Sect. Am. Soc. Anim. Sci. 34, 11 (abstract).

Knights, S. A., Baker, R. L., Gianola, D. and Gibb, J. B. (1984): Estimation of heritabilities and of genetic and phenotypic correlation among growth and reproductive traits in yearling Angus bulls. Anim. Sci. 58, 887-893.

Kress, D. D., Davis, K. C. and Tess, M. W. (1996): Adjusting scrotal circumference of yearling beef bulls in five composites. Can. J. Anim. Sci. 76, 189-191.

Kriese, L. A., Bertrand, J. K. and Benyshek, L. L. (1991): Age adjustment factors, heritabilities and genetic correlation for scrotal circumference and related growth traits in Hereford and Brangus bulls. J. Anim. Sci. 69, 478-481.

Laszczka, A. and Wierzbowski, S. (1984): An attempt to evaluate sperm production in adult bulls by means of a testis size index. Zuchthygiene 19, 218-244.

Latimer, F. G., Wilson, L. L. and Cain, M. F. (1982): Scrotal measurements in beef bulls: Heritability estimates, breed and test station effects. J. Anim. Sci. 54, 473-479.

Lunstra, D. D. (1985): Effect of single-sire and multiple-sire natural mating on pregnancy rate of beef cattle. Beef Research, Progress Report 2, 44-45. 
Lunstra, D. D., Gregory, K. E. and Cundiff, L. V. (1985): Heritability estimates and adjustment factors for yearling testicular size in different breeds of beef bulls. Beef Research, Progress Report 2, 41-43.

Lunstra, D. D., Gregory, K. E. and Cundiff, L. V. (1988): Heritability estimates and adjustment factors for the effects of bulls age and age of dam on yearling testicular size in breeds of bulls. Theriogenology 30, 127-136.

Moser, D. W., Bertrand, J. K., Benyshek, L. L., McCann, M. A. and Kiser, T. E. (1996): Effects of selection for scrotal circumference in Limousin bulls on reproductive and growth traits of progeny. J. Anim. Sci. 74, 2052-2057.

Neely, J. D., Johnson, B. H., Dillard, E. U. and Robinson, O. W. (1982): Genetic parameters for testes size and sperm number in Hereford bulls. J. Anim. Sci. 55, 1033-1040.

Polupan, Yu. (1994): Selection of bulls for scrotal circumference (in Russian, with English abstract). Zootekhniya 7, 29-30.

Pratt, S. L., Spitzer, J. C., Webster, H. W., Hupp, H. D. and Bridges, W. C. (1991): Comparison of methods for predicting yearling scrotal circumference and correlation of scrotal circumference to growth traits in beef bulls. J. Anim. Sci. 69, 2711-2720.

Schramm, R. D., Osborne, P. I., Thayne, W. V., Wagner, W. R. and Inskeep, E. K. (1989): Phenotypic relationships of scrotal circumference to frame size and body weight in performancetested bulls. Theriogenology 31, 495-503.

Shepard, H. H., Green, R. D., Golden, B. L., Hamlin, K. E., Perkins, T. L. and Diles, J. B. (1996): Genetic parameter estimates of live animal ultrasonic measures of retail yield indicators in yearling breeding cattle. J. Anim. Sci. 74, 761-768.

Smith, B. A., Brinks, J. B. and Richardson, G. V. (1987): Relationships of sire scrotal circumference with female growth and reproductive traits. $38^{\text {th }}$ Annual Beef Cattle Improvement Report and Sale Date, Technical Report, Colorado State University, 13-15 March.

Snedecor, G. W. and Cochran, W. G. (1976): Statistical Methods. $8^{\text {th }}$ ed. Iowa State Univ. Press, Ames, pp. 37-158.

Taylor, R. E. (1984): Beef Production and the Beef Industry. Burgers Publ., Minneapolis, pp. 209-214.

Temblador, S. R. and Gonzalez, A. J. (1988): Evaluation of sperm concentration and its possible relationship with testis circumference and length in bulls. Inform de Investigation, Instituto Tecnologico y de Estudios Superiores de Monterrey 20, 3-94.

Toelle, V. D. and Robinson, O. W. (1985): Estimation of genetic correlation between testicular measurements and female reproductive traits in cattle. J. Anim. Sci. 60, 89-99.

Tőzsér, J., Domokos, Z., Renaville, R., Mézes, M., Hidas, A. and Nagy, A. (1995): Evaluation of reproductive biological status in Charolais sire candidates and its integration in the selection index (in Hungarian, with English abstract). Állattenyésztés és Takarmányozás 44, 109-122.

Tőzsér, J., Mézes, M., Süpek, Z., Nagy, A. and Nagy, N. (1996): Age-related changes in scrotal circumference of Hungarian Simmental bulls in self-performance test. Acta Vet. Hung. 44, 263-267.

Tőzsér, J., Nagy, A., Póti, P., Süpek, Z., Domokos, Z. and Repovszki, J. (1993): Evaluation of scrotal circumference and scrotum characteristics in Charolais bulls prior to performance testing (in Hungarian). Állattenyésztés és Takarmányozás 42, 385-392.

Vargas, C. A., Olson, T. A., Elzo, M. A., Chase, C. C. and Chenoweth, P. J. (1997): Variance component estimates for scrotal circumference, age at puberty in heifers and hip height in Brahman cattle. J. Anim. Sci. 75 (Suppl. 1), 148 (abstract).

Wilson, D. E. (1996): Angus scrotal circumference genetic evaluation. Angus J. March Suppl. 9 (abstract)

Zhang, Y. C., Zhu, J., Xia, G. G., Lu, Q. and Zhang, X. X. (1993): The correlation of scrotal circumference with testosterone, androstenedione and corticosteroids in peripheral blood, and effects on semen quality in Holstein bulls. Acta Vet. Zootechn. Sinica 24, 399-404. 
